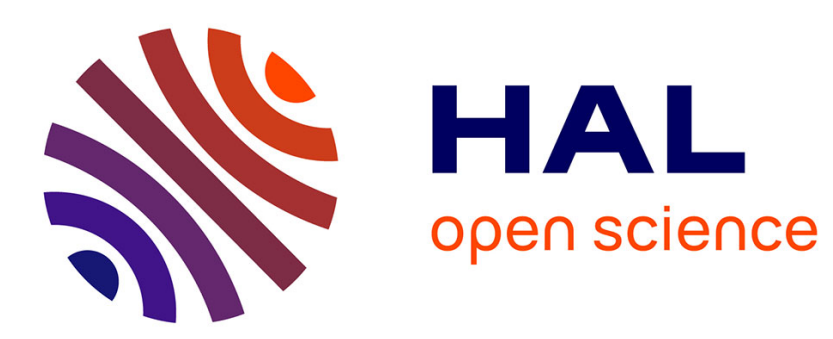

\title{
Synthesis of a New Modification of Lithium Chloride Confirming Theoretical Predictions
}

\author{
Martin Jansen, Andreas Bach, Dieter Fischer
}

\section{To cite this version:}

Martin Jansen, Andreas Bach, Dieter Fischer. Synthesis of a New Modification of Lithium Chloride Confirming Theoretical Predictions. Journal of Inorganic and General Chemistry / Zeitschrift für anorganische und allgemeine Chemie, 2009, 10.1002/zaac.200900357 . hal-00515815

\section{HAL Id: hal-00515815 \\ https://hal.science/hal-00515815}

Submitted on 8 Sep 2010

HAL is a multi-disciplinary open access archive for the deposit and dissemination of scientific research documents, whether they are published or not. The documents may come from teaching and research institutions in France or abroad, or from public or private research centers.
L'archive ouverte pluridisciplinaire HAL, est destinée au dépôt et à la diffusion de documents scientifiques de niveau recherche, publiés ou non, émanant des établissements d'enseignement et de recherche français ou étrangers, des laboratoires publics ou privés. 


\section{Synthesis of a New Modification of Lithium Chloride Confirming Theoretical Predictions}

\begin{tabular}{|c|c|}
\hline Journal: & Zeitschrift für Anorganische und Allgemeine Chemie \\
\hline Manuscript ID: & zaac. 200900357 \\
\hline Wiley - Manuscript type: & Article \\
\hline $\begin{array}{r}\text { Date Submitted by the } \\
\text { Author: }\end{array}$ & 27-Jul-2009 \\
\hline Complete List of Authors: & $\begin{array}{l}\text { Jansen, Martin; MPI für Festkörperforschung } \\
\text { Bach, Andreas; MPI fuer Festkoerperforschung, Chemie III } \\
\text { Fischer, Dieter; MPI fuer Festkoerperforschung, Chemie III }\end{array}$ \\
\hline Keywords: & $\begin{array}{l}\text { lithium chloride, polymorphism, structure elucidation, wurtzite, } \\
\text { atomic-beam-deposition }\end{array}$ \\
\hline
\end{tabular}

\section{S ScholaroNE" \\ Manuscript Central}




\section{Synthesis of a New Modification of Lithium Chloride Confirming Theoretical}

\section{Predictions}

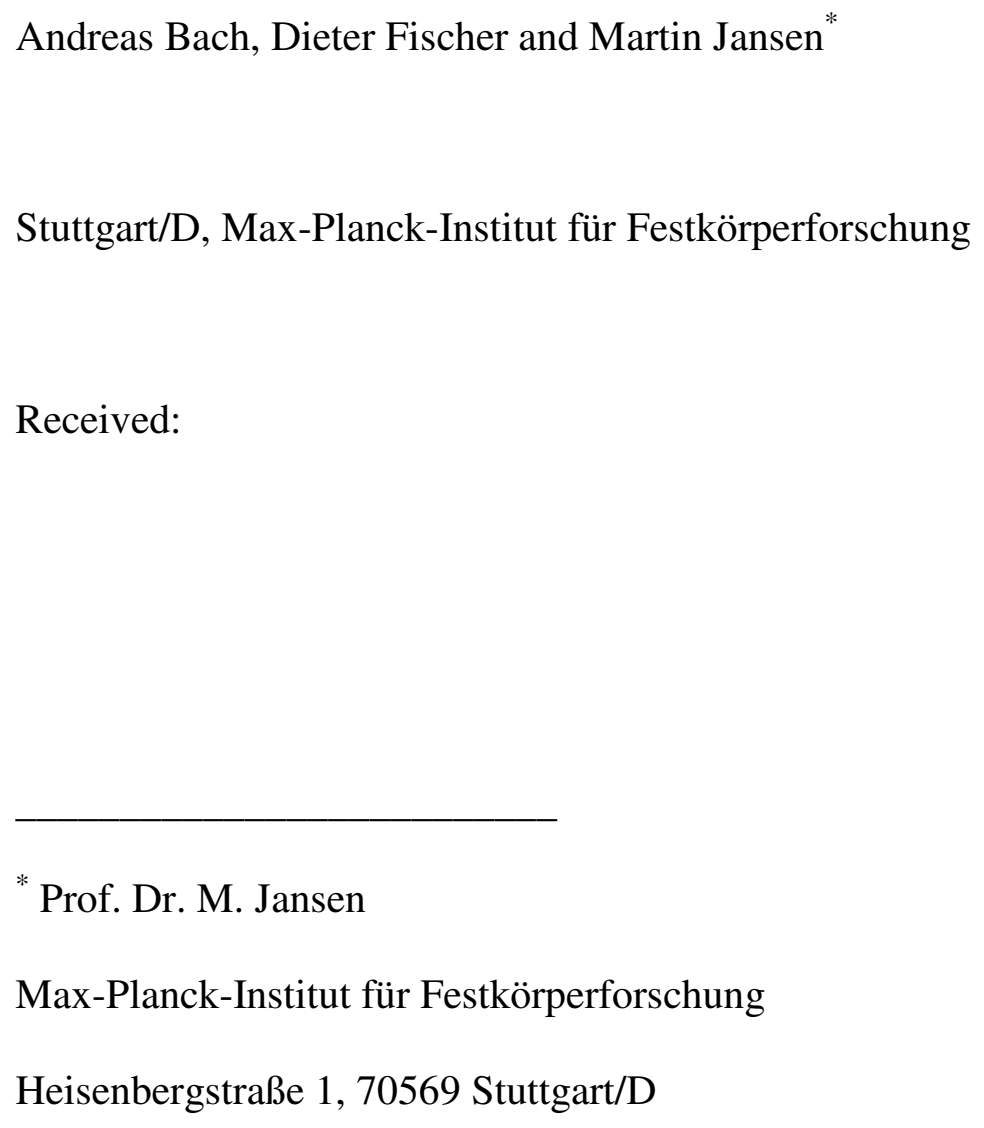

* Prof. Dr. M. Jansen

Max-Planck-Institut für Festkörperforschung

Heisenbergstraße 1, 70569 Stuttgart/D

Fax: +49(0)711-6891502, E-Mail: M.Jansen@ @ fkf.mpg.de 


\section{$\underline{\text { Abstract }}$}

In accordance with prior calculations, the new polymorph $\beta$ - $\mathrm{LiCl}$ (wurtzite structure type) has been synthesized, via the low-temperature atomic-beam-deposition (LT-ABD) technique, in a mixture with $\alpha-\mathrm{LiCl}$ (rock salt structure type) by depositing $\mathrm{LiCl}$ vapour ( 2 to $5.3 \cdot 10^{-4}$ mbar) onto a cooled substrate $\left(-30\right.$ to $\left.-60^{\circ} \mathrm{C}\right)$. The maximum $\beta$ - $\mathrm{LiCl}$ fraction of $53 \%$ was obtained using a sapphire (0001) substrate at $-50{ }^{\circ} \mathrm{C}$ and $3.7 \cdot 10^{-4} \mathrm{mbar} \mathrm{LiCl}$ vapour pressure. The proportion of the new polymorph contained in the bulk sample decreases as temperature or vapour pressure deviate from these values, until finally the rock salt type $\mathrm{LiCl}$ is found exclusively. When warming the samples up to room temperature, $\beta$ - $\mathrm{LiCl}$ irreversibly transforms to $\alpha$ - $\mathrm{LiCl}$. The $\mathrm{X}$-ray diffraction pattern of the two phase $\mathrm{LiCl}$ sample measured at $-50{ }^{\circ} \mathrm{C}$ has been indexed and refined based on a hexagonal unit cell for $\beta$ - $\mathrm{LiCl}$ with the lattice constants $a=3.852(1) \AA$ and $c=6.118(1) \AA$ and a cubic unit cell for $\alpha-\mathrm{LiCl}$ with the lattice constant $a=5.0630(8) \AA$. By Rietveld refinement the wurtzite type of structure $\left(P 6_{3} m c\right.$, No. 186) was suggested for the new hexagonal modification of $\mathrm{LiCl}$ with the $\mathrm{Li}-\mathrm{Cl}$ distances $(2.32$ and $2.34 \AA$ ) being $8 \%$ smaller than those of $\alpha-\mathrm{LiCl}$. Moreover the cell volume decreases as much as $16 \%$ during the transition from $\beta-\mathrm{LiCl}$ to $\alpha-\mathrm{LiCl}$. Both the shifts in bond lengths and volume correspond well with the situation encountered for $\mathrm{LiBr}$ and LiI. Besides the variation of $\mathrm{LiCl}$ vapour pressure and substrate temperature, also different substrate materials were employed for testing their influence on formation of the $\beta$ - $\mathrm{LiCl}$ polymorph.

Key words: lithium chloride, polymorphism, structure elucidation, wurtzite, atomicbeam-deposition 


\section{$\underline{\text { Introduction }}$}

Projecting the world of chemical matter onto an energy landscape associated to the respective configuration space constitutes the foundation of our approach to rational chemical synthesis [1-3]. There is a "one to one" relationship between the ensemble of chemical compounds capable of existence and the structure of the energy landscape: each compound corresponds to a (local) minimum on the landscape and vice versa. In the first step of synthesis planning the (meta)stable compounds of a given chemical subsystem are identified by globally exploring the related landscape, or more specifically, by identifying the minima. Realizing the predicted compounds, in particular the metastable ones, by chemical synthesis often turns out to be an intriguing task. Our approach of rational synthesis planning, the prediction and realization of new compounds, has proven to be rather efficient also with this respect [2], and among others, has enabled us to synthesize up to then elusive $\mathrm{Na}_{3} \mathrm{~N}$ [4].

Full exploration of the energy landscapes of the alkali metal halides has resulted in the prediction of many modifications to exist in addition to the known rock salt and $\mathrm{CsCl}$ types of structure [5]. For the lithium halides those modifications containing lithium in a tetrahedral coordination, i.e. zinc blende and wurtzite types, have turned out to be energetically competitive with the stable rock salt structures. Indeed, using the LT-ABD technique [6], $\beta$-LiI and $\beta$-LiBr have been realized in the hexagonal wurtzite structures, recently $[7,8]$. These findings are in a certain sense complying with the traditional structure field diagrams based on radii ratios of hard sphere ions. Here the stability range for an octahedral coordination, i.e. of the rock salt type, is $0.414 \leq r_{K} / r_{A} \leq 0.732$. LiI and $\mathrm{LiBr}$ with $r_{K} / r_{A}=0.35$ and 0.39 , respectively, are border line cases or even beyond this range [9]. In contrast, $\mathrm{LiCl}$ exhibiting a ratio of $r_{K} / r_{A}=0.42$ is clearly 
located within the stability range of the rock salt type. However, computational global searches and ab initio optimization of the structure candidates [5] have shown that for $\mathrm{LiCl}$ as well, the energies for the wurtzite and zinc blende modifications are rather low, as one can deduce from the energy versus volume curves displayed in Fig. 1.

Here, we report on our experiments aiming at realizing $\mathrm{LiCl}$ in one of the predicted metastable modifications.

\section{$\underline{\text { Results and Discussion }}$}

The deposition of $\mathrm{LiCl}$ onto various substrates at low temperatures via our LT-ABD technique [6] resulted in transparent films which changed into white opaque when warmed up to room temperature. With (0001)-oriented sapphire as substrate, the parameter field of deposition was explored. In the temperature range of -30 to $-60{ }^{\circ} \mathrm{C}$ and vapour pressures from 2 to $5.3 \cdot 10^{-4}$ mbar the new polymorph $\beta$ - $\mathrm{LiCl}$, besides $\alpha$ $\mathrm{LiCl}$, was found. The maximum $\beta$ - $\mathrm{LiCl}$ fraction of $53 \%$ was obtained at $-50{ }^{\circ} \mathrm{C}$ sapphire substrate temperature and $3.7 \cdot 10^{-4}$ mbar vapour pressure. The proportion of the new polymorph in the sample decreases as temperature or vapour pressure deviate from these optimal values. Finally, outside the parameter window given above for the substrate temperature and the vapour pressure, only rock salt structure type $\alpha-\mathrm{LiCl}$ is found. The fractions of $\beta$ - and $\alpha-\mathrm{LiCl}$ (wt \%) were calculated from Rietveld structure refinements and are displayed in Fig. 2. Here, the percentaged crystalline fraction of $\beta-\mathrm{LiCl}$ is shown as a function of substrate temperature and $\mathrm{LiCl}$ vapour pressure during deposition for different substrate materials. When heating the sample, $\beta$ - $\mathrm{LiCl}$ starts to transform to $\alpha-\mathrm{LiCl}$ around $0{ }^{\circ} \mathrm{C}$ with the phase transition completed at room temperature (Fig. 3). The X-ray diffraction pattern of the two phase LiCl sample measured at $-50{ }^{\circ} \mathrm{C}$ has been indexed and refined based on a hexagonal unit cell for 
$\beta-\mathrm{LiCl}(a=3.852(1) \AA ; \quad c=6.118(1) \AA)$ and the cubic unit cell for $\alpha-\mathrm{LiCl}$ ( $a=5.0630(8) \AA$ ). For the purpose of calibration, we used the lattice constant of $\alpha$-LiCl at room temperature $(a=5.131(1) \AA$; Lit.: $5.132 \AA$ [11]). The two phase Rietveld refinement, also addressing the effect of preferred orientation, suggested the wurtzite structure type $\left(P 6_{3} m c\right.$, No. 186) for the new hexagonal modification of LiCl (Fig. 4) with Li-Cl distances (2.32 and $2.34 \AA$ ) being $8 \%$ smaller than those of $\alpha$-LiCl (Tab. 1). Moreover the cell volume decreases as much as $16 \%$ during the transition from $\beta$ - $\mathrm{LiCl}$ to $\alpha$ - $\mathrm{LiCl}$. Both observations correspond well with the situation encountered for LiI and $\operatorname{LiBr}[7,8]$. A comparison of the cell parameters and volumes for different lithium halides shows that the results for $\mathrm{LiCl}$ in principle follow the trends as encountered for (both $\alpha$ - and $\beta$-) lithium halides with heavier halogens (Fig. 5). However, the decrease in volume for the cubic phases is larger as compared to the hexagonal ones.

The ratio of $\alpha-/ \beta-\mathrm{LiCl}$ appeared to be laterally constant within individual preparations, as monitored by X-ray diffraction. This is in accordance with the SEM pictures taken from the sample surface (Fig. 6) which do not show any noticeable variations in lateral direction. We attribute the microstructure observed to volume shrinkage at the transition from $\alpha$ - to $\beta$ - $\mathrm{LiCl}$. An increase of the crystallite size with increasing substrate temperature was observed. In addition to sapphire (0001), different surfaces of various single crystal materials have been tested as substrates. When using $\mathrm{ZnO}(0001), \mathrm{NaCl}$ (111) and cleaved $\mathrm{CaF}_{2}$ (111), no $\beta$ - $\mathrm{LiCl}$ was generated. The experiments on $\mathrm{ZnSe}$ (111) and $\mathrm{CaF}_{2}$ (111) resulted in amounts of $\beta$ - $\mathrm{LiCl}$ comparable to those on sapphire (0001) substrates. Due to these results no direct relations seem to exist between the selected substrate exposing a certain surface and the formation of $\beta$ - $\mathrm{LiCl}$. Hence, if at all, the substrate surface only plays an inferior role for the emergence of hexagonal $\mathrm{LiCl}$.

Furthermore, our results reveal a small window of synthesis parameter combinations (substrate temperature and vapour pressure), where $\beta$ - $\mathrm{LiCl}$ can be obtained, whith the 
substrate temperature being the more crucial factor of influence. In Fig. 2 is shown that $\beta$ - $\mathrm{LiCl}$ preferably forms at a substrate temperature of about $-45^{\circ} \mathrm{C}$. At a first glance it is hard to rationalize that $\alpha$ - and $\beta$ - $\mathrm{LiCl}$ crystallize simultaneously, and that the less stable polymorph survives together with the more stable one. The formation of $\beta$ - $\mathrm{LiCl}$, quite obviously, has thus to be attributed to non-equilibrium phenomena connected to the otherwise rather selective steps of nucleation and growth. Commonly, during the pre-stages of crystallization a dynamical population of subcritical nuclei develops, out of which those start to grow that reach the critical size and stability first. In our experiments, in a small temperature window local nucleation takes place at which the seeds for the different structure types do not appear to equilibrate or to undergo the common selection process. Instead of that, in the case of $\mathrm{LiCl}$, seeds start growing with the growth fed from the $\mathrm{LiCl}$ in the gas phase. If the substrate temperature is raised, thermal activation favours the transformation to the global minimum structure, i.e. the rock salt modification, and above $-30{ }^{\circ} \mathrm{C}$ substrate temperature $\alpha$ - $\mathrm{LiCl}$ is obtained exclusively. The parameter window is significantly smaller as compared to the cases of $\beta$ - $\mathrm{LiBr}$ and $\beta$-LiI $[7,8]$, and the temperature windows narrow from $\mathrm{LiI}\left(-196\right.$ to $\left.0{ }^{\circ} \mathrm{C}\right)$ to $\operatorname{LiBr}\left(-100\right.$ to $\left.-20^{\circ} \mathrm{C}\right)$ and $\mathrm{LiCl}\left(-60\right.$ to $\left.-30{ }^{\circ} \mathrm{C}\right)$.

These results confirm the high potential of the LT-ABD technique as to the formation of metastable compounds, though the parameter space needs to be explored very accurately to obtain the targeted possible polymorphs, and the parameter window for new polymorphs may be very small, like with $\mathrm{LiCl}$.

\section{$\underline{\text { Experimental Part }}$}

Lithium chloride $\left(99,99 \%\right.$, Aldrich) was dried at $200{ }^{\circ} \mathrm{C}$ in vacuum and directly evaporated from a home-made resistance heater (stenan crucible, Hoechst CeramTec 
AG) which was held at a constant temperature between 450 and $490{ }^{\circ} \mathrm{C}$, and deposited onto a cooled substrate inside a ultra high vacuum chamber for a period of several hours. Ultra high vacuum of $1 \cdot 10^{-8}$ to $5 \cdot 10^{-9}$ mbar was maintained during preparation in the deposition chamber by using a turbo molecular and cryopump system including a liquid nitrogen filled cold trap. The residual gas was analyzed and monitored by quadrupole mass spectrometers (QME 220, Pfeiffer Vacuum GmbH; C-100M, Leybold-Inficon). The substrate temperature (controlled using a temperature sensor PT-100 placed in the sample holder) was systematically varied from $-196^{\circ} \mathrm{C}$ to room temperature during deposition and X-ray diffraction measurement, and the vapour pressure of $\mathrm{LiCl}$ in a range between 1 and $8 \cdot 10^{-4}$ mbar (calculated from crucible temperature). The deposition rates and the deposited layer thicknesses were controlled using a quartz crystal monitor (QCM, Inficon). Deposited $\mathrm{LiCl}$ was harvested quantitatively, and the amount of lithium in the sample was determined by ICP-OES in order to calibrate the QCM. Film thicknesses of up to a few hundreds of nanometers were achieved. The following materials were used as substrates (all CrysTec GmbH): sapphire (0001), $\mathrm{ZnO}(0001), \quad \mathrm{ZnSe}(111), \mathrm{CaF}_{2}$ (111), $\mathrm{NaCl}$ (111) (all epitaxial polished) and cleaved $\mathrm{CaF}_{2}$ (111). The substrates with the deposited samples were transferred from the deposition chamber to an X-ray diffractometer, while maintaining vacuum and cooling, by means of a car transfer system.

The powder diffraction patterns were recorded on a $\theta / \theta$ X-ray powder diffractometer (D8-Advance, Bruker AXS) with parallel beam geometry (Goebel mirror, $\mathrm{Cu}_{\mathrm{K} \alpha}$ ) in an X-ray chamber under ultra high vacuum (ca. $5 \cdot 10^{-8}$ mbar) in reflection mode. The chamber is supplied with a slit to absorb scattered radiation which considerably reduces the background under vacuum condition from $20^{\circ}$ on in $2 \theta$. Each X-ray pattern was monitored at an angle of incidence of $10^{\circ}$ using an area sensitive detector (GADDS, Bruker AXS). The corresponding pattern was obtained by integration of the two 
dimensional diffraction cones. X-ray measurements over the whole sample area revealed very low values of local fluctuations. For indexing and structure refinements (Rietveld method), the software Topas (Version 3.0, 2006, Bruker AXS) was employed [10]. $\alpha-\mathrm{LiCl}$ served as an internal standard. Further details on the crystal structure investigations can be obtained from the Fachinformationszentrum Karlsruhe, 76344 Eggenstein-Leopoldshafen, Germany (fax: (+49) 7247-808-666; e-mail: crysdata@fizkarlsruhe.de) on quoting the depository numbers XX. 


\section{$\underline{\text { References }}$}

[1] J. C. Schön, M. Jansen, Angew. Chem. 1996, 108, 1358; Angew. Chem. Int. Ed. 1996, 35, 1286.

[2] M. Jansen, Angew. Chem. 2002, 114, 3896.

[3] J. C. Schön, M. Jansen, Int. J. Mat. Res. 2009, 100, 135.

[4] D. Fischer, M. Jansen, Angew. Chem. Int. Ed. 2002, 41, 1755.

[5] Ž. Čančarević, J. C. Schön, M. Jansen, Chem. Asian J. 2008, 3, 561.

[6] D. Fischer, M. Jansen, J. Am. Chem. Soc. 2002, 124, 3488.

[7] D. Fischer, A. Müller, M. Jansen, Z. Anorg. Allg. Chem. 2004, 630, 2697.

[8] Y. Liebold Ribeiro, D. Fischer, M. Jansen, Angew. Chem. Int. Ed. 2008, 47, 4428.

[9] U. Müller, Anorganische Strukturchemie, 6. Auflage, Vieweg+Teubner, Wiesbaden 2008, p. 82.

[10] A. A. Coelho, Topas, General Profile and Structure Analysis Software for Powder Diffraction Data, Version 3.0, Bruker AXS GmbH, Karlsruhe, Germany, 2006.

[11] W. P. Davey, Phys. Rev. 1923, 21, 143.

[12] Determination of the structure candidates by semilocal gradient dependent functional DFT calculation (Becke-PWGGA), $\mathrm{Li}$ and $\mathrm{Cl}$ with an all-electron basis set (AEBS).

[13] G. J. Finch, S. Fordham, Proc. Phys. Soc. 1936, 48, 85. 
Tab.1: Crystallographic data for the Rietveld refinement of $\mathrm{LiCl}$

chemical formula

molar mass [ $\mathrm{g} \mathrm{mol}^{-1}$ ]

temperature

$\mathrm{Cu} \mathrm{K} \mathrm{K}_{\alpha}$ wavelength, $\lambda[\AA]$

measured range $(2 \theta)$

$\mathrm{R}_{\mathrm{p}}[\%]^{\mathrm{a})}$

$\mathrm{R}_{\mathrm{wp}}[\%]^{\mathrm{a})}$

$\beta$-LiCl

space group

$\mathrm{Z}$

cell parameters $[\AA]$

cell volume $\left[\AA^{3}\right]$

$\rho_{\text {calc }}\left[\mathrm{g} \mathrm{cm}^{-3}\right]$

cry size $[\mathrm{nm}]$

no. of reflections

Li site

$\mathrm{Cl}$ site

preferred orientation

$\mathrm{B}_{\text {eq }}$

$\mathrm{R}_{\text {Bragg }}[\%]^{\text {a) }}$

$\underline{\alpha-\mathrm{LiCl}}$

space group

$\mathrm{Z}$

cell parameter $[\AA]$

cell volume $\left[\AA^{3}\right]$

$\rho_{\text {calc }}\left[\mathrm{g} \mathrm{cm}^{-3}\right]$

cry size [nm]

no. of reflections

Li site

Cl site

preferred orientation

$\mathrm{B}_{\mathrm{eq}}$

$\mathrm{R}_{\text {Bragg }}[\%]^{\text {a) }}$
$\mathrm{LiCl}$

42.4

$-50{ }^{\circ} \mathrm{C}$

$1.54059,1.54449$

$11-88^{\circ}$

4.2

5.6

hexagonal

$P 6_{3} m c$ (no. 186)

2

$\mathrm{a}=3.852(1)$

$\mathrm{c}=6.118(1)$

78.65(4)

1.8

26.0(2)

20

(2b) $1 / 3,2 / 3,0$

(2b) $1 / 3,2 / 3,0.379^{b)}$

(002): 0.406(2)

$0.2(1)$

2.1

cubic

Fm3; $;^{-} m$ (no. 225)

4

$\mathrm{a}=5.0630(8)$

129.78(6)

2.2

24.3(4)

8

(4a) 0, 0, 0

(4b) $1 / 2,1 / 2,1 / 2$

(111): $0.3(1)$

(022): 0.3(2)

3.5

1.9

\footnotetext{
${ }^{a)} R_{p}, R_{w p}, R_{\text {Bragg }}$ and March-Dollase function for the preferred orientation as defined in Topas Version 3.0. [10]

b) Unrefined sites, taken from $\mathrm{LiBr}$
} 
Fig. 1: E/V curves for selected candidates for low-energy structures discovered by global searches of the $\mathrm{LiCl}$ energy landscape, followed by local optimization of each polymorph on the ab initio level $\left(\mathrm{E}_{\text {Min=Wurzite }}=-467.86573\right.$ Hartree $)[5,12]$

Fig. 2: Percentaged crystalline fraction of $\beta-\mathrm{LiCl}[\mathrm{wt}-\%]$ as determined by Rietveld refinements of the two phase $\alpha-/ \beta-\mathrm{LiCl}$ samples as a function of substrate temperature and vapour pressure of $\mathrm{LiCl}$ (calculated from crucible temperature) during deposition

Fig. 3: X-Ray powder patterns of $\mathrm{LiCl}$ (deposited at $-50{ }^{\circ} \mathrm{C}$ sapphire substrate temperature and $3.7 \cdot 10^{-4} \mathrm{mbar} \mathrm{LiCl}$ vapour pressure), intensity deviation due to texture, scans from the bottom up: taken at $-50{ }^{\circ} \mathrm{C}$ (wurtzite and rock salt type), $0{ }^{\circ} \mathrm{C}$ (wurtzite and rock salt type) and $25{ }^{\circ} \mathrm{C}$ (rock salt type), tick marks: $\alpha \mathrm{LiCl}$

Fig. 4: Rietveld refinement plot of $\mathrm{LiCl}$ (deposited at $-50{ }^{\circ} \mathrm{C}$ sapphire substrate temperature and $3.7 \cdot 10^{-4} \mathrm{mbar} \mathrm{LiCl}$ vapour pressure), two phase refinement, measured at $-50{ }^{\circ} \mathrm{C}$; observed pattern (blue), fitted profile (red), difference profile (grey), tick marks: $\alpha$ - $\mathrm{LiCl}$ (black), $\beta$ - $\mathrm{LiCl}$ (green)

Fig. 5: Cell parameters of wurtzite (left) and rock salt modifications (right) of different lithium halides as determined by Rietveld refinements, LiI (measured at $25^{\circ} \mathrm{C}$ ) [7], $\mathrm{LiBr}[8,13]$ and $\mathrm{LiCl}$ (measured at $-50{ }^{\circ} \mathrm{C}$ )

Fig. 6: SEM picture showing homogeneity of $\mathrm{LiCl}$ surface, 350-fold magnification, deposited at $-45^{\circ} \mathrm{C}$ sapphire substrate temperature and $3.7 \cdot 10^{-4} \mathrm{mbar} \mathrm{LiCl}$ vapour pressure, after warming up to $120^{\circ} \mathrm{C}$ 


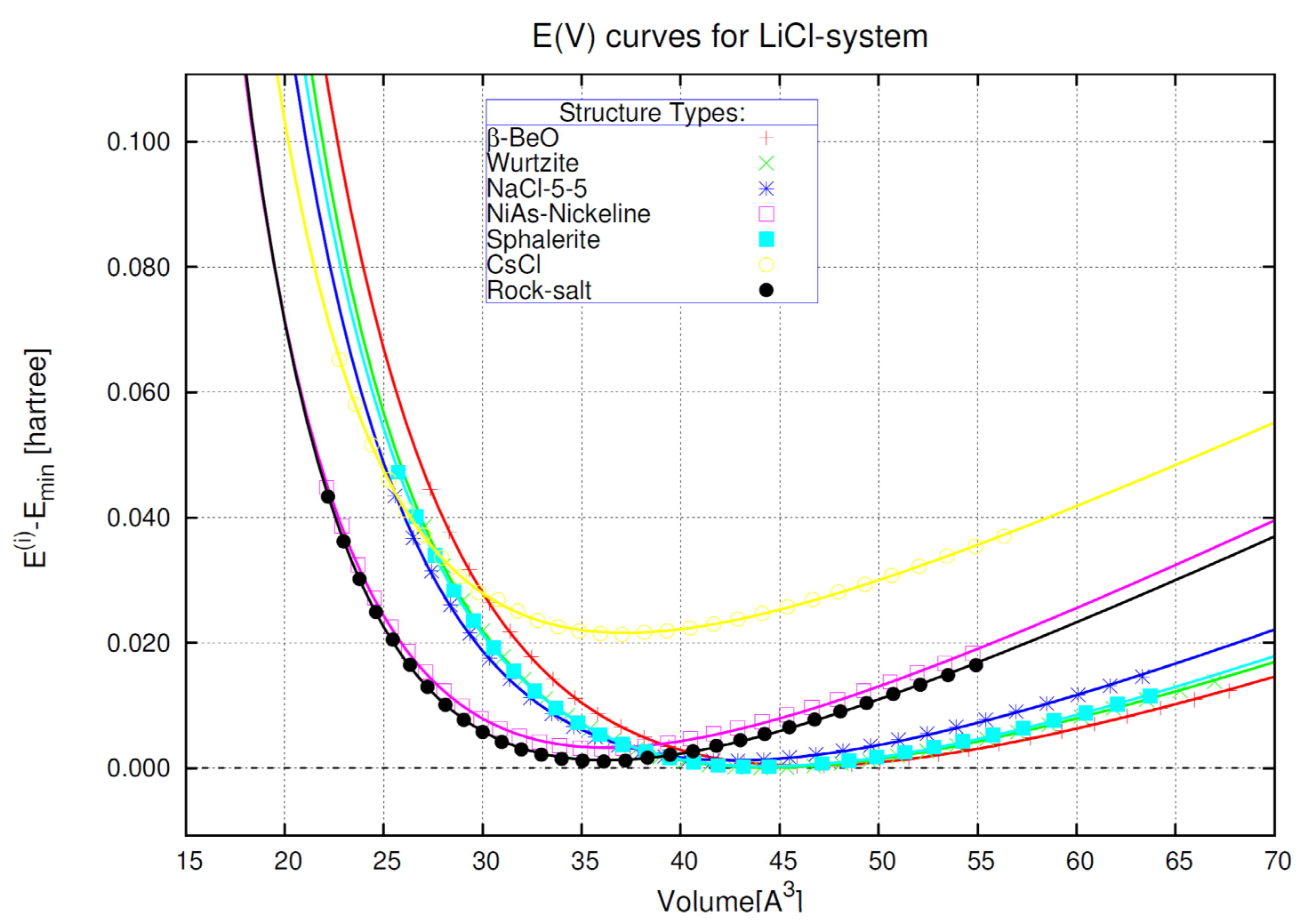

1

3

4

5

6

9

10

11

12

13

14

15

16

17

18

19

20

21

22

23

24

25

26

27

28

29

30

31

32

33

34

35

36

37

38

39

40

41

42

43

44

45

46

47

48

49

50

51

52

53

54

55

56

57

58

59

60 
Andreas Bach, Dieter Fischer and Martin Jansen

Fig. 1 


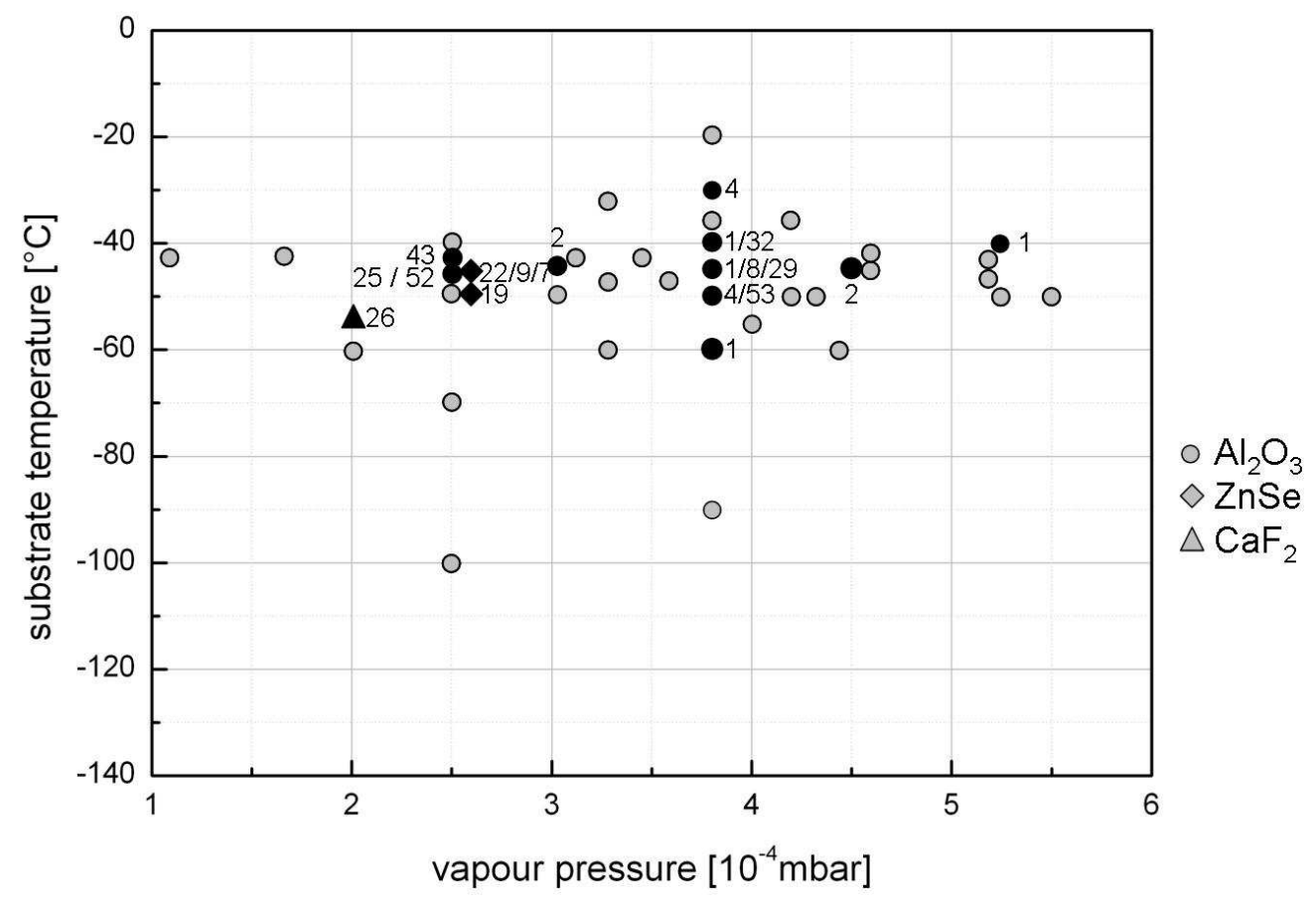


Andreas Bach, Dieter Fischer and Martin Jansen Fig. 2 


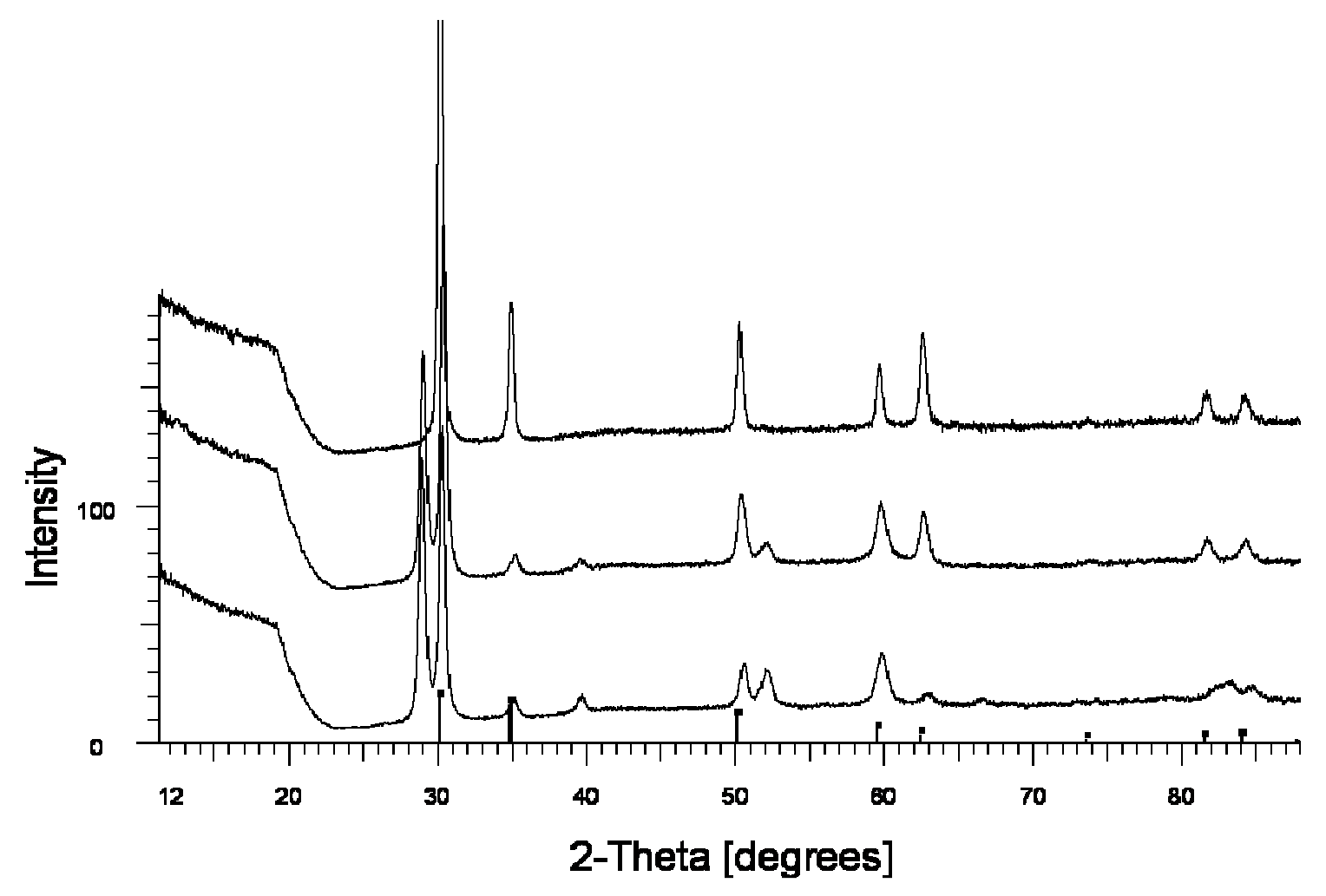


Andreas Bach, Dieter Fischer and Martin Jansen Fig. 3 


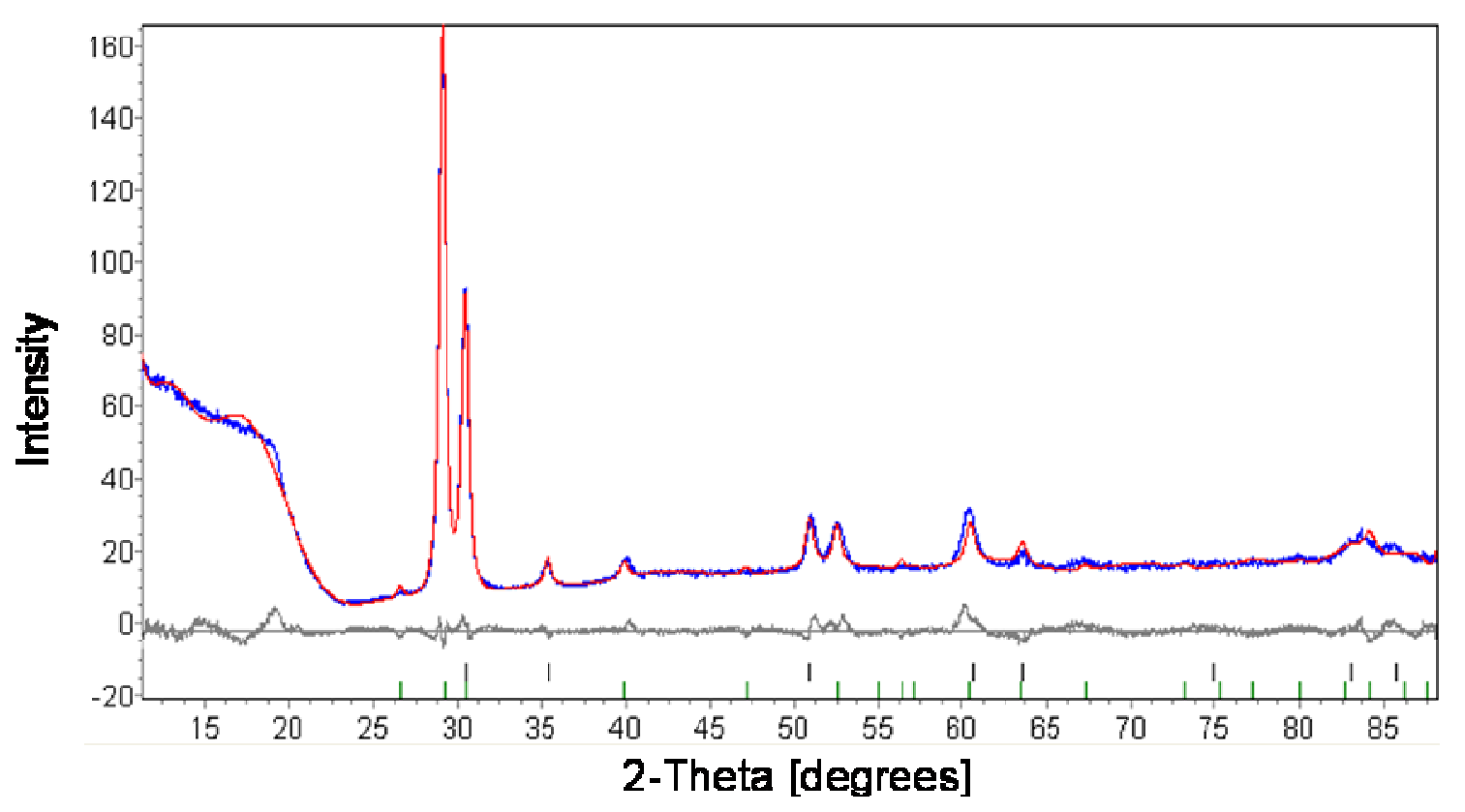


Andreas Bach, Dieter Fischer and Martin Jansen Fig. 4 

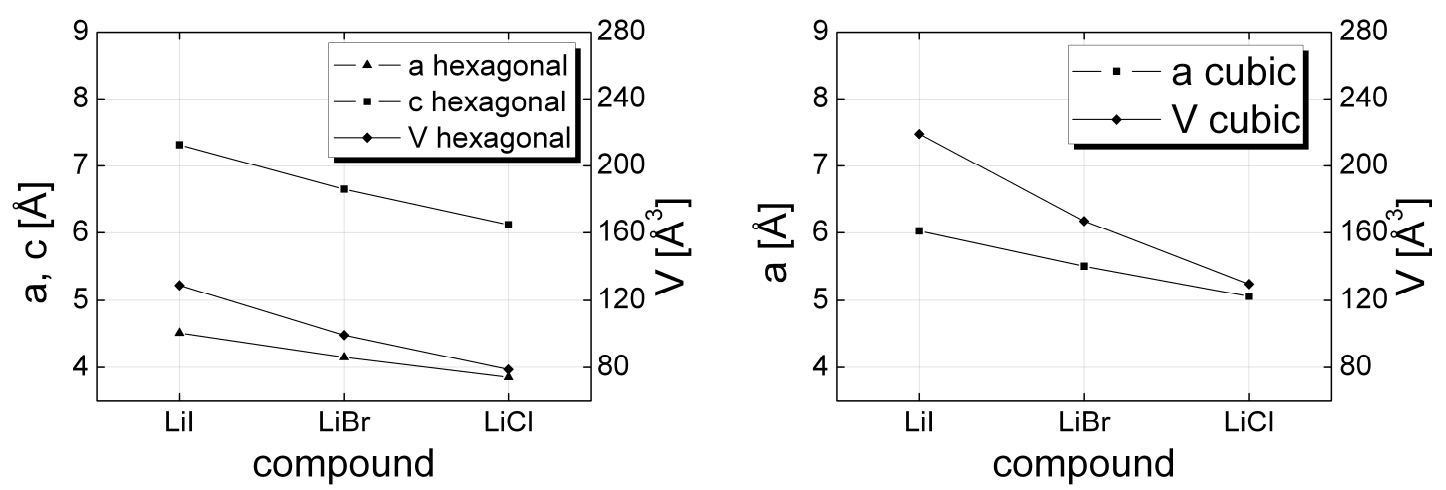

16

17

18

19

20

21 
Andreas Bach, Dieter Fischer and Martin Jansen Fig. 5 


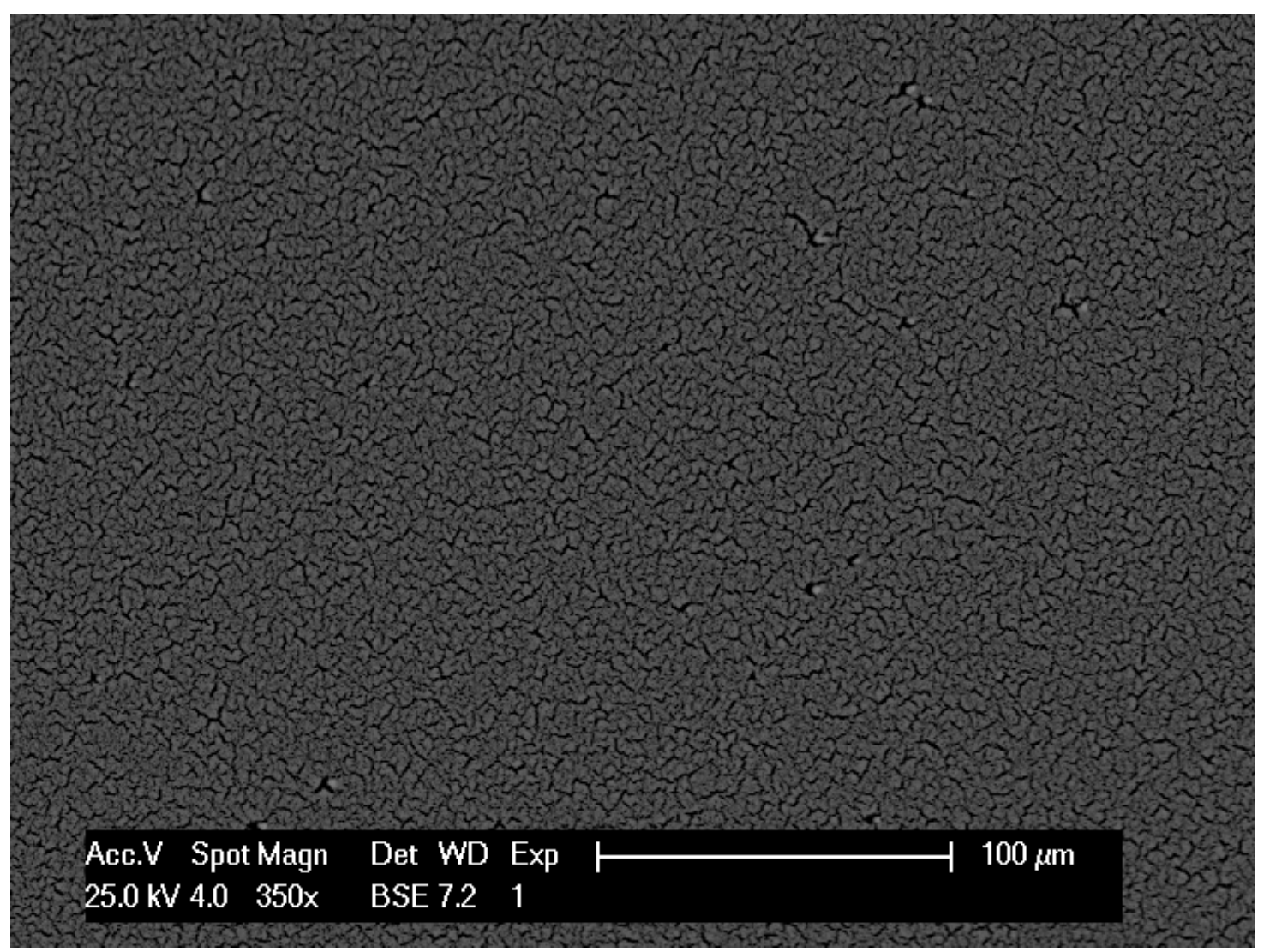


Andreas Bach, Dieter Fischer and Martin Jansen Fig. 6 


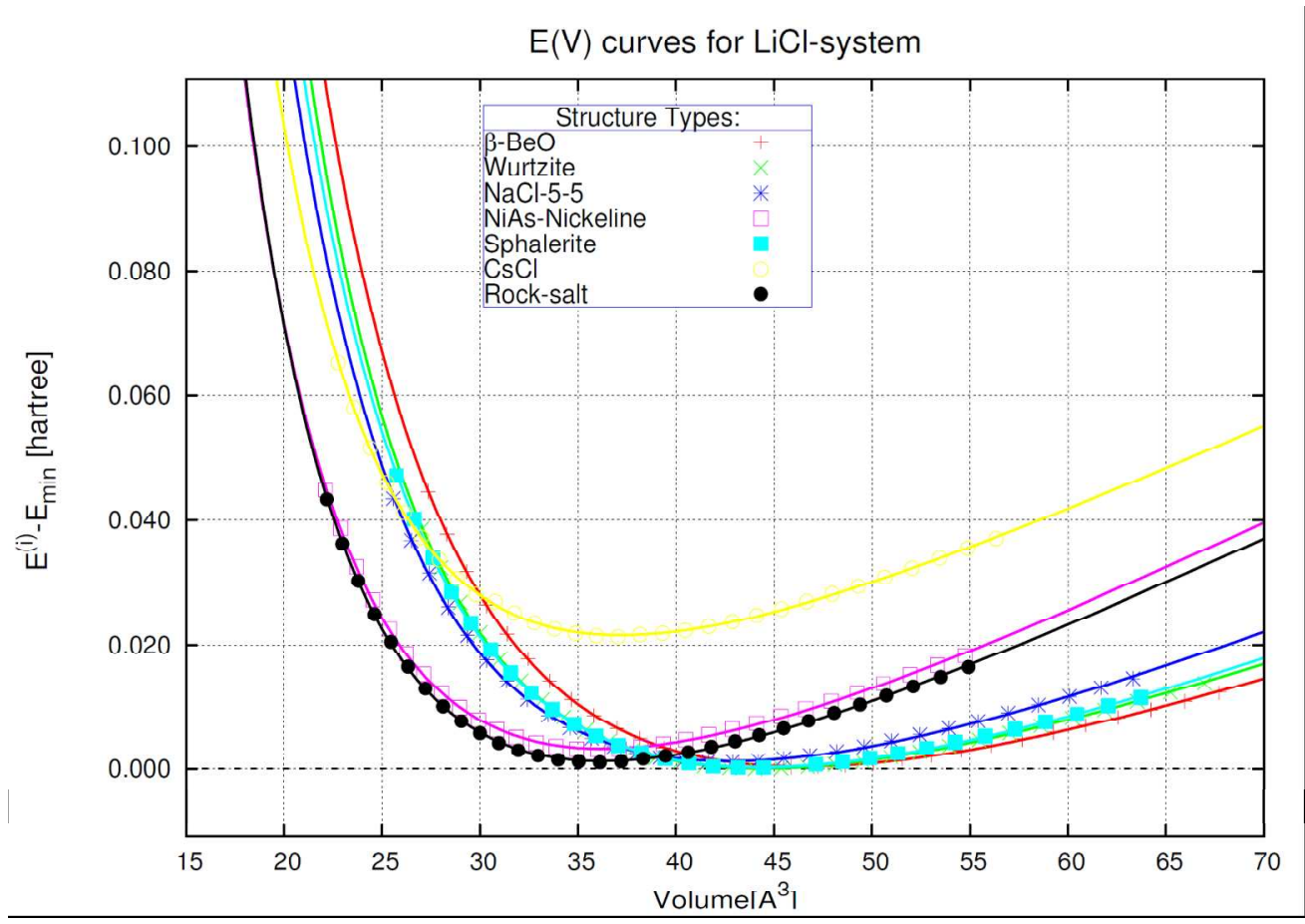

$1880 \times 1321 \mathrm{~mm}(96 \times 96 \mathrm{DPI})$ 


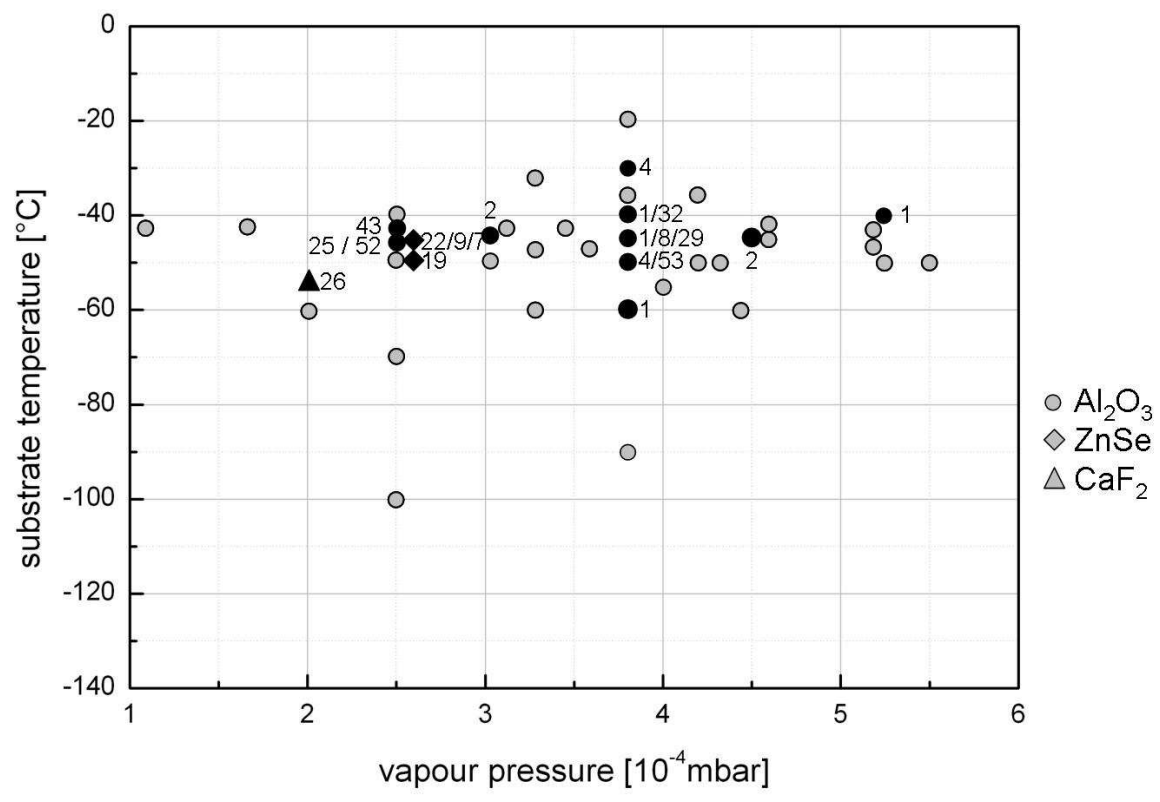

$254 \times 179 m m(150 \times 150$ DPI $)$ 


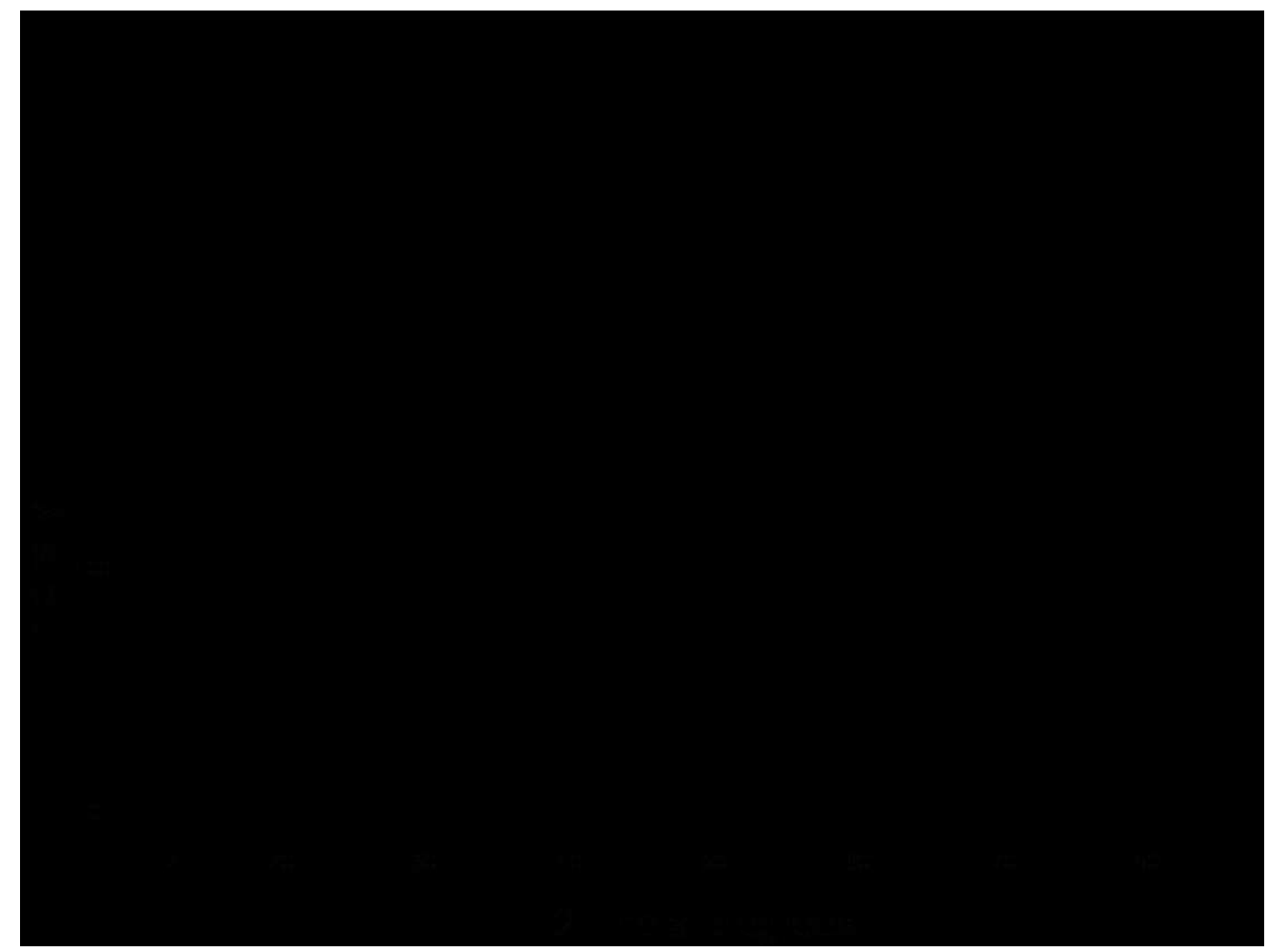

278x198mm (102 x 108 DPI) 


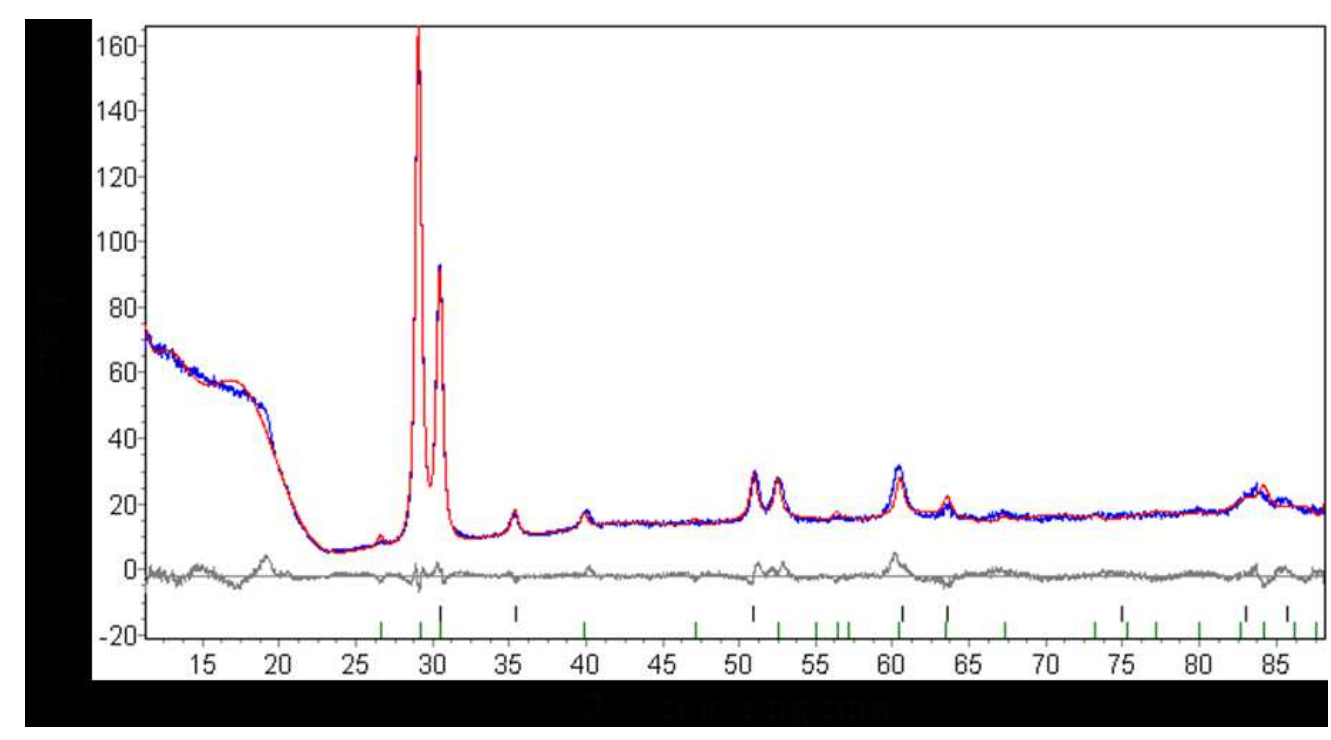

$154 \times 84 \mathrm{~mm}(150 \times 150 \mathrm{DPI})$

1

2

3

4

5

6
7

8

9

10

11

12

13

14
15
16

16

17

18

19

20

21

22

23

24

25

26

27

28

29

30

31

32

33

34

35

36

37

38

39

40

41

42

43

44

45

46

47

48

49

50

51

52

53

54

55

56

57

58

59

60 


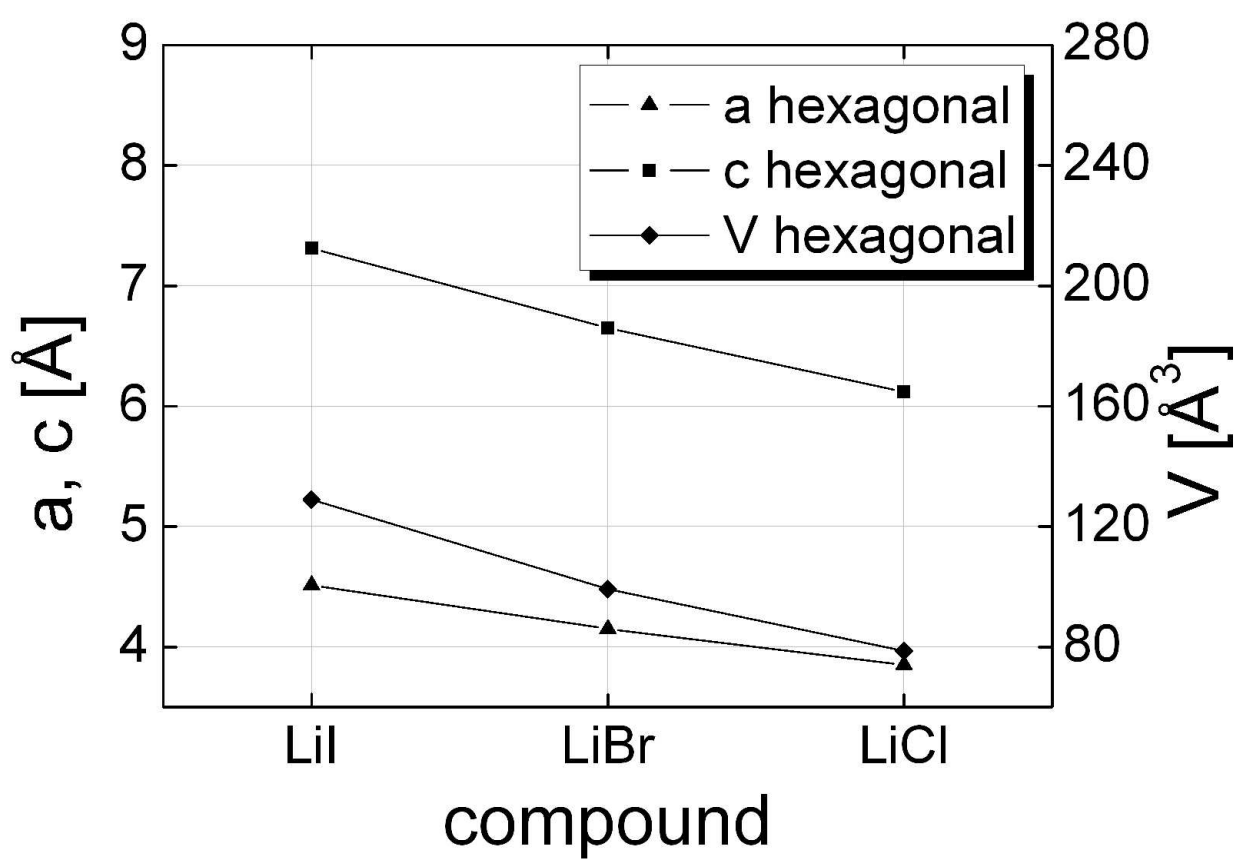

$287 \times 203 \mathrm{~mm}(300 \times 300$ DPI $)$ 


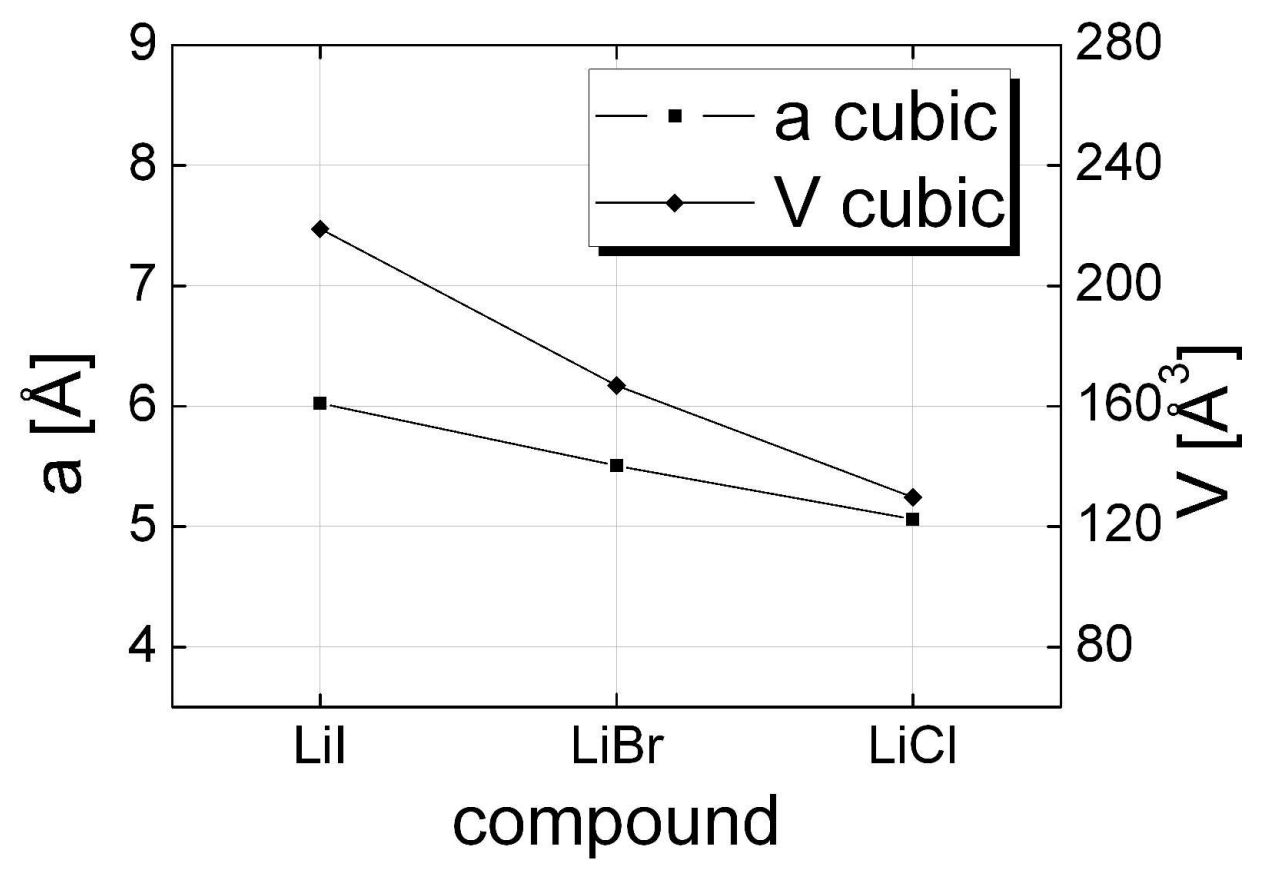

$287 \times 203 \mathrm{~mm}(300 \times 300$ DPI $)$ 


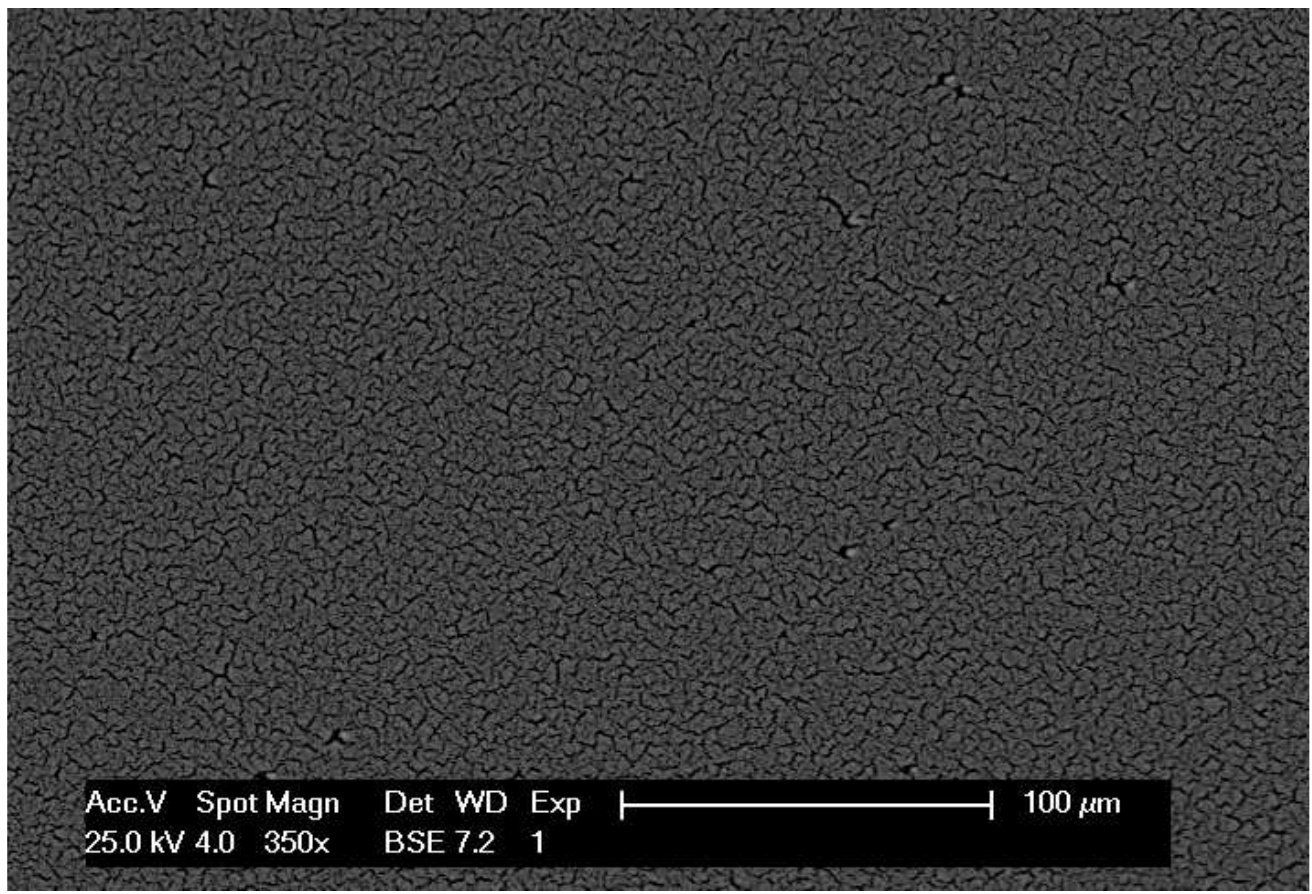

